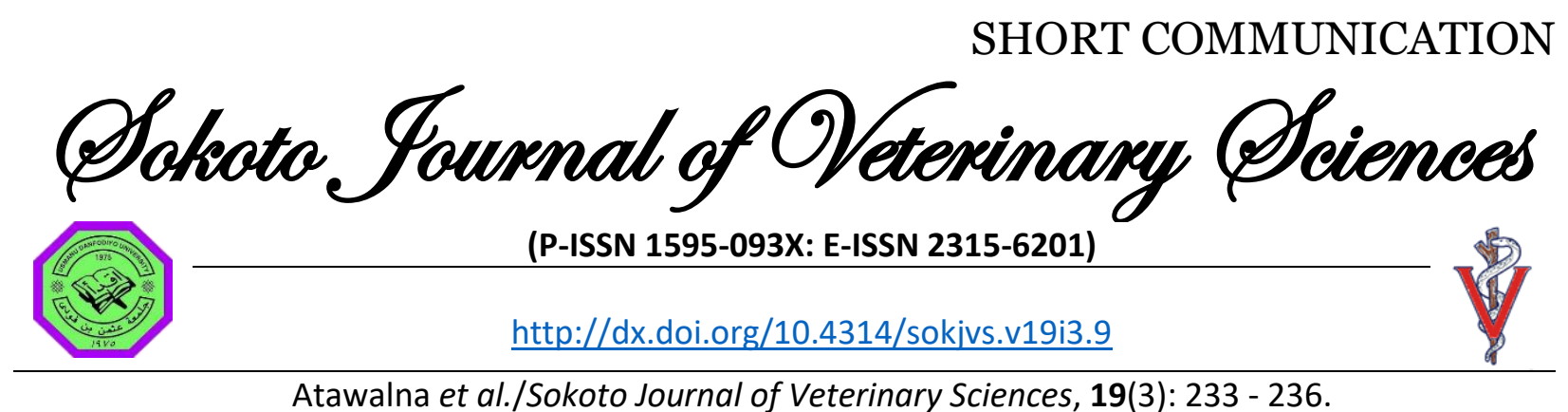

\title{
Gross testicular morphometric parameters and sperm reserves in indigenous Ghanaian West African dwarf goats
}

\author{
J Atawalna, D Essel-Cobbinah, PD Akpalu \& BO Emikpe* \\ School of Veterinary Medicine, Kwame Nkrumah University of Science and Technology Kumasi, Ghana
}

*Correspondence: Tel.: +233549410841; E-mail: banabis2001@yahoo.com

\begin{abstract}
Copyright: (c) 2021
Atawalna et al. This is an open-access article published under the terms of the Creative Commons Attribution License which permits unrestricted use, distribution, and reproduction in any medium, provided the original author and source are credited.
\end{abstract}

Publication History: Received: 09-02-2021 Revised: 19-04-2021 Accepted: 12-05-2021

\begin{abstract}
The West African Dwarf (WAD) goat has genetic potentials that can be exploited for improved goat production. However, their testicular morphometric parameters and sperm reserves in Ghana are not well known. A cross-sectional study was conducted at the Sabtiu Musah abattoir in Kumasi, Ghana, to evaluate the gross testicular morphometric parameters and sperm reserves in 10 indigenous WAD goats. The samples were stored on an ice chest and transported to the Regional Veterinary Laboratory for analysis on the day of collection. In the laboratory, the testes and epididymis were separated by dissection and then freed of all connective tissue and the Tunica albuginea. The weight, length, width and volume of the testis were determined. A segment of testicular parenchyma was incised and homogenized in a $20 \mathrm{ml}$ normal saline solution. The resulting homogenate was stored in the refrigerator overnight and a filtered aliquot used for estimating spermatid concentration and sperm reserves. The weight, length, width, volume of the testis and the gonadosomatic index were 70.09 $\pm 14.19 \mathrm{gm}, 7.46 \pm 0.52 \mathrm{~cm}, 5.08 \pm 0.62, \mathrm{~cm}, 102.40 \pm 29.40 \mathrm{ml}$ and $5.09 \pm 0.07 \%$, respectively. The sperm reserves per the whole testis, sperm reserves per gramme testis, Daily Sperm production (DSP), and DSP per gramme testis of Ghanaian WAD bucks were $146.0 \pm 50.95,2.2 \pm 0.62,41.01 \pm 14.3$ and $0.62 \pm 0.17 \times 10^{9}$ spermatozoa, respectively. Indigenous West African Draft goats have a high potential for sperm production. It is recommended that further research be conducted on the semen quality parameters of this breed.
\end{abstract}

Keywords: Daily sperm production, Dwarf goat, Morphometry, Sperm reserves, West African

\section{Introduction}

Small ruminants plays an essential role in the economies of many developing countries. In Ghana, the population of goats stands at 6,352,000 (MOFA, 2016). The major breeds of goats reared in Ghana include the West African dwarf (WAD) goat and the long-legged Sahelian goat. However, WAD is a significant component of the indigenous livestock genetic resources, especially in the rural communities of Ghana (Birteeb \& Lomo, 2015). The National Goat Breeding Station at Kintampo and similar breeding stations have been mandated to improve the WAD goat (Birteeb et al., 2015).

Small ruminants in Sub Saharan Africa have been observed to have low genetic potential (Chukwuka et al., 2010), usually associated with high kid mortality and inbreeding. The genetic improvement of the 
WAD goat will involve the selection of superior breeding stock and artificial insemination. The selection of superior males will rely on breeding soundness examination of bucks. The identification of potential good breeders based on an assessment of semen quality parameters alone may not be satisfactory (Al-Ghalban et al., 2004). According to Ritar et al. (1992), the estimation of gonadal and extragonadal sperm reserves in conjunction with assessment of semen quality parameters is more reliable than the former. Sperm reserves have been determined from slaughtered domestic animals (Abba \& Igbokwe 2015) and found to be positively correlated to testicular weight and scrotal circumferences in bucks (Ajani et al., 2015). Scarce information is available in Ghana on the reproductive capacity of indigenous bucks. This study, therefore, sought to investigate morphometric parameters and gonadal sperm reserves in indigenous WAD bucks.

\section{Materials and Methods}

This study was conducted at the Sabtiu Musah abattoir in the Kumasi metropolis in July 2020. This abattoir is located at the centre of the metropolis and is designated for the slaughter of small ruminants. The metropolis is located between Latitude $6.35^{\circ} \mathrm{N}$ and $6.40^{\circ} \mathrm{S}$ and between longitude $1.30^{\circ} \mathrm{W}$ and $1.35^{\circ} \mathrm{E}$ and lies 250 to 300 meters above sea level (GSS, 2014). The metropolis is within the humid forest zone of Ghana and experiences a rainy season from April to November, and a dry season from December to March annually. The average daily temperatures ranges from $21.5-30.7^{\circ} \mathrm{C}$, with an annual rainfall of $1147 \mathrm{~mm}$.

Table1: Gross Testicular parameters of West African Dwarf Goats

\begin{tabular}{ll}
\hline Parameter & Mean \pm Standard deviation \\
\hline Testis weight/gm & $70.09 \pm 14.19$ \\
Testis length/cm & $7.46 \pm 0.52$ \\
Testis width/cm & $5.08 \pm 0.62$ \\
Testis volume/ml & $102.40 \pm 29.40$ \\
GSI (\%) & $5.09 \pm 0.07$ \\
\hline
\end{tabular}

GSI-gonadosomatic index

Table 2: Sperm reserves $\left(x 10^{9}\right)$ of West African Dwarf Goats

\begin{tabular}{lll}
\hline Parameter & $\begin{array}{l}\text { Mean } \pm \\
\text { deviation }\end{array}$ & Standard \\
\hline $\begin{array}{l}\text { Sperm reserves / testis } \\
\text { Sperm reserves / gramme }\end{array}$ & $2.2 \pm 0.62$ \\
testis & \\
DSP / testis & $41.01 \pm 14.3$ \\
DSP / gramme testis & $0.62 \pm 0.17$ \\
\hline
\end{tabular}

DSP-daily sperm production
The scrotal sacs with the testis and epididymis from ten randomly selected WAD bucks were purchased from butchers after slaughter. The live body weights of the bucks were estimated to be $25-30 \mathrm{~kg}$. The collected samples were stored on an ice chest and transported to the Regional Veterinary Laboratory for analysis on the day of collection. At the laboratory, the testes and epididymis were separated by dissection and freed of all connective tissue and the Tunica albuginea. The testis was weighed to the nearest gm using an electronic meter scale (HRB series, HR1212004a, China) Model, number, country. The length and width of the testis were measured using a flexible tape measure. The volume of the testis was estimated using the formula for a prolated spheroid as follows: $V=4 / 3 \pi(1 / 2 L)(1 / 2 W)^{2}$ (RamírezBautista \& Gutiérrez-Mayén, 2003). A segment of testicular parenchyma was incised, and $20 \mathrm{ml}$ of normal saline solution $(0.9 \% \mathrm{NaCl}$ solution) was added and then thoroughly minced in a blender. The blender was rinsed with a further $10 \mathrm{ml}$ of normal saline. The resulting homogenate was stored in the refrigerator for overnight. The homogenate was filtered the next day. Estimates of the sperm concentration in tissue suspensions were made after 24 hours of storage at $5^{\circ} \mathrm{C}$ as Amann \& Almquist (1961) indicated. The diluted samples were examined for spermatid concentration using a modified Neubauer haemocytometer, as Ogunlade et al. (2006) described.

The gonadal sperm reserves per testis were obtained by the product of the respective volume of the testis and spermatozoa concentration of the homogenate. The daily sperm production was obtained by dividing

the gonadal sperm reserves by a reported time divisor of 3.56 for bucks (Ritar et al., 1992). The gonadosomatic index (GSI, \%) was estimated as the ratio of left testicular weight multiplied by 2 , relative to average body weight for all selected breeds of goat bucks. Using computer software, the data obtained were summarized as means \pm standard deviations (GraphPad, 2018).

\section{Results and Discussion}

For the first time, this study presents gross testicular parameters of indigenous WAD bucks in Ghana (Table 1). The weight, length, width, volume of the testis and the GSI were 70.09 $\pm 14.19 \mathrm{gm}, 7.46 \pm 0.52 \mathrm{~cm}, 5.08 \pm 0.62, \mathrm{~cm}$, $102.40 \pm 29.40 \mathrm{ml}$ and $5.09 \pm 0.07 \%$, respectively. The sperm reserves per the whole 
testis, sperm reserves per gramme testis, Daily Spermatozoa production (DSP), and DSP per gramme testis of indigenous WAD bucks were $146.0 \pm 50.95$, $2.2 \pm 0.62,41.01 \pm 14.3$ and $0.62 \pm 0.17$ billion spermatozoa, respectively (Table 2 ). This study presents the gross testicular parameters of indigenous WAD bucks in Ghana. The testicular weight (TW) of Ghanaian WAD bucks in this study was similar to $64.67 \pm 3.17$ gm reported for WAD bucks in the Guinea Savannah zone in Nigeria (Ezihe et al., 2017). On the contrary, TW was considerably higher than $26.87 \pm 1.36 \mathrm{gm}$ reported for WAD bucks in Makurdi, Nigeria (Onugwu et al., 2018). The reason for this variation is due to the different geographical origins of study animals and the season of the year. The WAD bucks in this study were located in the forest zone, whereas those in the latter were found in the savannah zone, where forage is scarce during the drier months of the year. The testicular weight (TW) of WAD bucks in this study was higher than $52.53 \pm$ $11.28 \mathrm{gm}$ reported for Sahelian bucks in the humid regions of Nigeria (Oyeyemi et al., 2012) and $61.79 \pm$ 1.69gm in Maiduguri (Stephen et al., 2019).

The testis length (TL) was higher than $5.95 \pm 0.31 \mathrm{~cm}$ (Ugwu, 2009) and $5.19 \pm 0.11 \mathrm{~cm}$ (Onugwu et al., 2018) for WAD bucks in Nsukka and Makurdi, respectively. The smaller testis size in the latter was due to relatively young, post-pubertal bucks recruited for the study. On the other hand, TL was lower than $8.93 \pm 0.27 \mathrm{~cm}$ reported for the same breed in Nigeria (Ezihe et al., 2017). The testicular width (TWd) for WAD bucks in this study was higher than $3.19 \pm 0.23$ cm (Ugwu, 2009) for WAD bucks in Nsukka, Nigeria. This variation in width was due to age differences and degree of sexual maturity. The study animals were more matured than the latter. Similarly, the TWd was higher than $4.72 \pm 0.69 \mathrm{~cm}$ reported for Sahelian bucks in the humid regions of Nigeria (Oyeyemi et al., 2012), but lower than values for Sahelian bucks in Maiduguri (Abba \& Igbokwe, 2015; Stephen et al., 2019), where TWd values of $9.81 \pm 0.22 \mathrm{~cm}$ and 9.29 $\pm 0.91 \mathrm{~cm}$, respectively. This study's testis volume was higher than $55.40 \pm 0.59 \mathrm{~cm}^{3}$ (Ugwu, 2009) for WAD bucks in Nsukka, Nigeria.

The gonadosomatic index of Ghanaian WAD bucks in the study was higher than $3.51 \pm 0.69 \%$ in Nigerian Sahelian goats (Abba \& Igbokwe, 2015). Similarly, the GSI was comparatively higher than Shami, mountain black and hybrid Jordanian goat bucks (Omari et al., 2018). These breeds were reported to have GSI values of $3.55 \pm 0.52,3.65 \pm 0.41$ and $3.75 \pm 0.52 \%$ respectively. The testicular sperm reserves per gramme testis in this study was similar to the values of 0.03-1.88 billion cells reported in Nigeria (Abba \& Igbokwe, 2015), but higher than sperm reserves for Jordanian goat bucks (Omari et al., 2018). Daily sperm production (DSP) and daily sperm production per gramme testis (DSPG) in this study were higher than $3.32 \pm 0.45$ and $1.22 \pm 0.01$ billion cells, reported for Nigerian adult WAD bucks (Bitto \& Egbunike, 2006). According to these authors, gonadal sperm reserves, DSP and DSPG were similar ( $P>0.05)$ during the rainy and dry seasons. The WAD buck is therefore not a seasonal breeder in its native environment. There is no evidence that the potential for sperm production differed between WAD and Sahel breeds (Alade et al., 2006).

In conclusion, West African Draft goats in Ghana have a high potential for sperm production. It is recommended that further research be conducted on the semen quality parameters of this breed (Alade et al., 2006).

\section{Acknowledgements}

The authors wish to thank the management and staff of the Nutrition Laboratory of the Department of Animal Science and the Clinical Analysis Laboratory of the University of Science and Technology (KNUST), Kumasi, for technical assistance.

\section{Conflict of interest}

The authors declare that there is no conflict of interest.

\section{References}

Abba Y \& Igbokwe IO (2015). Testicular and related size evaluations in Nigerian Sahel goats with optimal cauda epididymal sperm reserve. Veterinary Medicine international, doi.10.1155/2015/357519.

Ajani OS, Oyeyemi MO \& Moyinoluwa OJ (2015). Correlation between ages, weight, scrotal circumference and the testicular and epididymal parameters of Red Sokoto Bucks. Journal of Veterinary Medicine and Animal Health, (5): 159-163.

Alade NK, Shettima AA \& Watirahyel IB (2006). Differences between the testicular and semen quality characteristics of three breeds of goats in a semi- arid environment. Journal of Arid Agriculture, 16: 145-149.

Al-Ghalban AM, Tabbaa MJ \& Kridli RT (2004). Factors affecting semen characteristics and scrotal circumference of Shami bucks. Small Ruminant Research, 53(1-2): 141-149. 
Amann RP \& Almquist JO (1961). Technique for direct measurement of gonadal and extragonadal sperm reserves. Journal of Dairy Sciences, 44(8): 1537-1543.

Birteeb PT \& Lomo R (2015). Phenotypic characterization and weight estimation from linear Body traits of West African Dwarf goats reared in the transitional zone of Ghana. Livestock Research for Rural Development, 27, Article number 175.

Birteeb PT, Danquah BA \& Salifu ARS (2015). Growth performance of West African dwarf goats reared in the transitional zone of Ghana. Asian Journal of Animal Sciences, 9(6): 370378.

Bitto II \& Egbunike GN (2006). Seasonal variations in sperm production, gonadal and extragonadal sperm reserves in pubertal West African dwarf bucks in their native tropical environment. Livestock Research for Rural Development. 18, Article number 134.

Chukwuka OK, Okoli IC, Okeudo, NJ, Opara MN, Herbert U, Ogbuemu IP \& Enkenyem BU (2010). Reproductive Potentials of West African Dwarf Sheep and Goat: A review. Research Journal of Veterinary Sciences, 3(2): 86-100.

Ezihe CO, Namo AV \& Sule D (2017). Reproductive Parameters of the West African dwarf bucks raised in the guinea savannah zone of Nigeria. Nigerian Journal of Biotechnology, doi.10.4314/njb.v32i1.3.

GraphPad Prism (2018). Version 8. http://www.graphpad .com/scientificsoftware/prism

GSS (2014). Population and Housing census. District Analytical Report. Kumasi Metropolitan. Pp 1-2.

MOFA (2016). Agriculture in Ghana: Facts and Figures. Pp 32.

Ogunlade JT, Ewuola EO, Gbore FA, Bandyopadhyay, R, Niezen J \& Egbunike GN (2006). Testicular and epididymal sperm reserves of rabbits fed fumonisin contaminated diets. World Applied Science Journal, 1(1): 35-38.

Omari H, Al-Dawood A \& Althenebat A (2018). Testicular and epididymal sperm reserve evaluations in three Jordanian goat breeds, Journal of Applied Animal Research, doi.10.1080/09712119.2018.1552152

Onugwu NC, Addass PA \& Momoh M O (2018). Assessment of the reproductive potentials of intact and unilateral cryptorchid bucks of West African Dwarf (WAD) goats in Makurdi. International Journal of Agriculture and Earth Science, 4(3): 17-23.

Oyeyemi MO, Fayomi, AP, Adeniji, DA \& Ojo KM (2012). Testicular and epididymal parameters of Sahel buck in the humid zone of Nigeria. International Journal of Morphology, 30(2): 489-492.

Ramírez-Bautista A \& Gutiérrez-Mayén G (2003). Reproductive Ecology of Sceloporus utiformis (Sauria: Phrynosomatidae) from a Tropical Dry Forest of México. Journal of Herpetology, 37(1): 1-10.

Ritar AJ, Mendoza G, Salamon S \&White IG (1992). Frequent semen collection and sperm reserves of the male Angora goat (Capra hircus). Journal of Reproduction and Fertility, doi.10.1530/jrf.0.0950097.

Stephen J, Malle T, Bukar, MM, Yusuf, ZB, Maina, VA \& Wahid MA (2019). Comparative study on characteristics of semen collected from sahel bucks using slicing swim up and mincing flushing technique. Direct Research Journal of Veterinary Medicine and Animal Science, 4(1): 5-10.

Ugwu SOC (2009). Relationship between scrotal circumference, in situ testicular measurements and sperm reserves in the West African dwarf bucks. African Journal of Biotechnology, 8(7): 1354-1357. 